\title{
MICROBIOLOGICAL RISK ASSESSMENT OF FISHERY PRODUCT IN INDONESIA: A PROPOSED MODEL FOR THE RISK OF Vibrio parahaemolyticus IN SHRIMP
}

\section{Kajian Resiko Mikrobiologi terhadap Produk Perikanan di Indonesia: Rancangan Model untuk Resiko Vibrio parahaemolyticus pada Udang}

\author{
Novalia Rachmawati*) and Radestya Triwibowo \\ Research and Development Center for Marine and Fisheries Product Processing and Biotechnology \\ ${ }^{*}$ Correspondence Author: novalia@kkp.go.id. KS. Tubun Petamburan VI Jakarta Pusat 10260
}

\begin{abstract}
Increasing fish consumption value should be supported by enhancing the safety and quality of fish products. Microbiological level is most of importance since every food contains microorganisms which could multiplicate due to temperature abuse and time delay during handling and processing. Risk assessment is a structurally and scientifically based approach aimed to protect consumer from risk (hazard) particularly microbiological hazard when consuming certain food. Microbiological risk assessment of fishery products have not been structurally developed in Indonesia, eventhough several initial data on hazard identification have been available. As an attempt to build an integrated risk assessment, a model for microbiological risk of pathogenic Vibrio parahaemolyticus in shrimp will be proposed in this article. The available data could be used as a starting point while other required data could be collected in collaboration with other related institutions.
\end{abstract}

Keywords: microbiological risk assessment, Vibrio parahaemolyticus, shrimp

\begin{abstract}
ABSTRAK
Peningkatan nilai konsumsi produk perikanan sudah seharusnya didukung dengan peningkatan keamanan dan kualitas produk perikanan. Keamanan mikrobiologi menjadi sangat penting mengingat setiap makanan mengandung mikroorganisme yang dapat berkembang dengan cepat apabila tidak ditangani dan diproses dengan baik dan benar (pada suhu dan waktu yang tepat). Kajian resiko merupakan suatu pendekatan yang terstruktur dan berdasarkan pada kaidah ilmiah yang bertujuan untuk memberikan perlindungan kepada konsumen dari resiko (bahaya), dalam hal ini bahaya mikrobiologi, yang muncul apabila mengkonsumsi suatu makanan. Kajian resiko mikrobiologi produk perikanan belum terlaksana dengan baik di Indonesia, meskipun beberapa data awal yang mendukung kajian tersebut telah dipublikasikan. Sebagai salah satu upaya untuk membangun kajian resiko mikrobiologi yang terintegrasi, dalam artikel ini akan dipaparkan tentang rancangan model untuk kajian resiko pada Vibrio parahaemolyticus patogen pada udang. Data yang sudah ada dapat dijadikan sebagai data awal dalam kajian ini, sedangkan data lain yang masih dibutuhkan dapat diperoleh bersama-sama dengan instansi lain yang terkait.
\end{abstract}

Kata Kunci: kajian resiko mikrobiologis, Vibrio parahaemolyticus, udang

\section{INTRODUCTION}

\section{THE NEED FOR MICROBIOLOGICAL RISK ASSESSMENT (MRA)}

The average of Indonesian's fish consumption value increases from $30.48 \%$ in 2010 to $31.64 \%$ in 2011 (MMAF, 2011b). This value should be followed by the enhancement of quality and safety assurance of fishery products in the market to provide a consumer protection. In general, the quality and safety of food is determined by physical, chemical and microbiological criteria. Microbiological criteria comes into the most important one because every food naturally contains microorganisms (which might include pathogenic bacteria) and the amount of the microorganisms might increases due to many factors such as temperature abuse, time delay and contamination during handling. In addition, as a tropical region, Indonesia serves as the most suitable 
environment for the growth of foodborne microorganisms (Miraglia et al., 2009).

Indonesia also has potential export markets for fishery products such as EU, USA and Japan. The increasing average from export value of Indonesian fishery products at the period of $2007-2011$ has reached $11.27 ; 7.90$ and $5.66 \%$ for EU, USA and Japan market respectively (MMAF, 2011b). At the same time, safety requirement for internationally marketed products become more stringent. Therefore effort to maintain the amount of microorganisms in food like good sanitation and hygienic system which combined with well-performed Hazard Analysis and Critical Control Points (HACCP) application is fundamental in a production line. Cold chain system during handling and processing also play an important role to assure the wholesomeness of the products is maintained properly.

Risk assessment is aimed to protect consumer from hazard which may occur from consuming fishery products. The result of risk assessment can be used as a scientific input in the product's standard preparation. In the international trade and market, food quality standard and regulation applied in every nation should be based on scientific approaches. However, risk assessment in Indonesia is not well performed yet. In particular for fishery products, the main causative agent of hazard is microbiological hazard (pathogenic bacteria). Available data on microbiological risk assessment is also very limited. Therefore attempts to build a complete risk assessment need to be done immediately.

\section{FOODBORNE CASE}

Foodborne case is usually caused by the consumption of contaminated food. Instead of chemical, the contamination is mainly due to pathogenic bacteria (CDC, 2005). Foodborne can be categorized as infection and intoxication. Infection occurs when a person consumes food contaminated with microorganisms such as Salmonella sp., Campylobacter jejunii, Eschericia coli, Listeria monocytogenes, Yersinia sp., Shigella sp., Enterobacter, Citrobacter, and Calcivirus (Norwalklike virus). These microorganisms multiply in the human body and produce toxin. While intoxication occur when a person consumes food which already contains toxin from several microorganisms such as Bacillus cereus, Clostridium botulinum, and Staphylococcus aureus (EFSA, 2011).

Prediction of foodborne cases in the US is 76 million cases per year (CDC, 2005). Recent data reported that 8 people experienced an acute diarrhea after consuming Crayfish which was suspected to be contaminated by Vibrio mimicus during handling and 60 people suffered due to consumption of raw mussel which was suspected to be contaminated by Campylobacter (Rotschild, 2010; Shreck, 2010). In European Union, it was reported that 45.2 cases of Campylobacteriosis and 31.1 cases of Salmonellosis occurs per 100.000 people in 2007 (ECDC, 2010).

The National Development Planning Board (Badan Perencanaan Pembangunan Nasional-BAPPENAS) (2007) reported foodborne outbreaks in Indonesia are mainly caused by contamination of Staphylococcus aureus, Bacillus cereus, Salmonella sp. and E. coli strain pathogen. However, supported data such as the number of cases, level of severity and mortality, dose exposure (level of contaminations) is not well documented.

\section{QUALITY ASSURANCE AND RAPID ALERT SYSTEM}

Quality assurance system is required in every processing steps of fishery product. In Indonesia, Ministry of Marine Affairs and Fisheries (MMAF) has published several regulation related to quality and safety assurance of fishery products, i.e. Decree of the Minister of Marine Affairs and Fisheries of The Republic of Indonesia no. 1 year 2007 regarding Requirements for Quality Assurance and Safety of Fishery Products during Production, Processing and Distribution; Regulation of the Minister of Marine Affairs and Fisheries of The Republic of Indonesia no. 15 year 2011 regarding Control of Quality and Safety Assurance System of Fishery Product Imported to Republic of Indonesia; and Regulation of the Minister of Marine Affairs and Fisheries of The Republic of Indonesia no. 19 year 2010 regarding Control of Quality and Safety Assurance System of Fishery Product. Technical implementation of those regulations is translated into a Regulation published by the Head of Agency of Fish Quarantine, Quality Control and Safety of Fishery Product no. 3 year 2011 regarding Technical Guidance for Application of Quality Assurance System and Safety of Fishery Product. These regulations contain requirements for imported fishery products which should be completed by health and quality certificates from the countries of origin and provide information that the product meets the standard requirement of microbiological and chemical contamination. Improper products may lead to import rejection.

On the other hand, the obligation for domestically industries and fish processing units (Unit Pengolah 
Ikan - UPI) to apply for certification is still semi mandatory. Socialization on the application of quality assurance system is an ongoing process until fish processing units ready for certification. Bearing in mind that Indonesian's fish consumption rate is increasing about $10.7 \%$ per year for the period of 2002 -2005 (BAPPENAS, 2007) and the target of MMAF to increase the fish consumption value of $32.7 \mathrm{~kg} /$ capita/y in 2012 (MMAF, 2011a), further awareness on the production and domestic market is also necessary.

The export value of fishery product from Indonesia has reached 529 million tons in 2011. Frozen fish has the biggest value with 341 million tons, while shrimp has the second biggest value with 49 million tones followed by fresh fish with 21 million tones (BKIPM, 2012). In 2009, the value of exporting products from Indonesia to USA has reached USD 2.47 million as in Japan it has reached USD 360 million in 2010 (JETRO, 2011).

From 1999 to 2002, the most rejection cases of fishery product exported to European Union were originated from Asian region with the most contamination agent is are Vibrio spp, Salmonella and several Enterobacteriaceae. About $75 \%$ of the contamination by Vibrio was found in frozen shrimp. Furthermore, in 2001 - 2003, the most rejection cases in Japan were mostly caused by Coliform and E. coli (Ababouch et al., 2005). Rejection cases from fishery products exported to USA increased from 27 cases in October 2011 to 56 cases in November 2011. About $68 \%$ of the cases were caused by contamination of Salmonella (FDA, 2011).

Developed countries have applied rapid alert systems for food which does not comply with the requirement. Such a system is called Rapid Alert System for Food and Feed (RASFF) which aimed to give protection for consumers in European Union. Based on the reported data from RASFF in 2010 for microbiologically contaminated food, 233 notifications cases were due to contamination of Salmonella, 57 cases were due to contamination of $L$. monocytogenes (including salmon and catfish products) and 32 cases reported were due to contamination of $E$. coli in shellfishes (EC, 2011).

Recent cases in US were recalled of cold smoked salmon, salmon sushi fillet and salmon trim in $24^{\text {th }}$ November 2011 because the product may be contaminated with L. monocytogenes (Desk, 2011) and recalled of herring fillet in oil in $12^{\text {th }}$ January 2012 because the product contains $L$. monocytogenes (US FDA, 2012). In Canada, during 2011, 32 products were recalled due to $L$. monocytogenes contamination, 48 cases due to $E$. coli and 1 case due to Salmonella contamination. And during 2012, 4 fishery products have been recalled due to contamination of $L$. monocytogenes (CFIA, 2012).

Number of recalls notified in Australia and New Zealand over the past ten years (January 2000 to December 2010) shows the majority of cases were due to bacterial contamination (36\% of total cases), followed by labeling errors. From 711 recorded cases, the most common contaminants are $L$. monocytogenes, Salmonella, and E. coli (FSANZ, 2012).

Loss from foodborne cases consist of many aspects. Aside from medication loss, foodborne cases also caused a huge financial loss. For example in 1994, USA has spent approximately USD $10-83$ billion for recall of uncomply products in the market by responsible industries and for corrective action taken by government (FDA, 1997 in Huss et al, 2004).

However, rapid alert system and recalling procedure of contaminated food in Indonesia are not well integrated yet. Data on microbiological contamination of fishery products are mostly obtained from export rejection report. Therefore MMAF has established the Agency of Fish Quarantine Quality Control and Safety (Badan Karantina Ikan, Pengendalian Mutu dan Keamanan Hasil Perikanan) as a competent authority to protect fish resources of Indonesian waters from any disease and perform quality and safety assurance of fishery products. The agency supported by 45 technical units located at the exit and entry points in several provinces of Indonesia.

\section{FOOD SAFETY RISK ASSESSMENT}

Risk assessment is a component of risk analysis in food (WHO/FAO, 2008). Risk analysis contains of 3 main components (Fig. 1), i.e.:

- Risk Assessment to identify the risk and factor that influence

- Risk Management to show how the risk can be controlled or prevented

- Risk Communication to inform other on the risk that might occur

Food and Agriculture Organization (FAO) and World Health Organization (WHO) have responsibilities to develop and standardize Microbiological Risk Assessment (MRA) at the international level as well as informing risk managers at national and international levels. Through the ad hoc Joint FAO/ WHO Expert Meetings on Microbiological Risk Assessment (JEMRA) body, FAO and WHO 


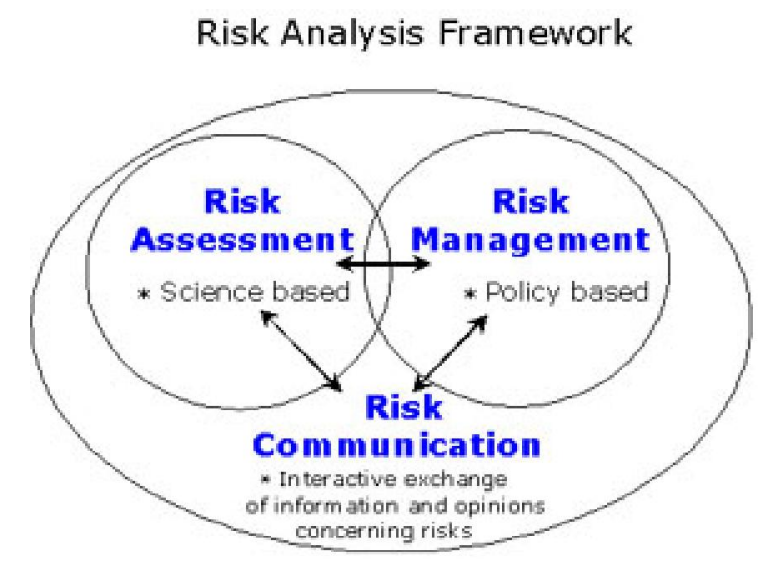

Figure 1. Components of Risk Analysis (WHO/FAO, 2008).

responsible to conduct MRA in food at the international level (WHO/FAO, 2008).

Risk assessment is usually done by government because it deals with impact estimation of hazards in foods to public health. The risk analysis provides information on acceptable level of pathogenic microorganisms or acceptable prevalence of a product. The acceptable level can be achieved by the implementation of Hazard Analysis and Critical Control Point (HACCP) together with Good Manufacturing Practice (GMP), Good Hygienic Practice (GHP) and Total Quality Management (TQM) by industries (Fig. 2) (Forsythe, 2002; Schothorst, 2002).

\section{MICROBIOLOGICAL RISK ASSESSMENT (MRA)}

Microbiological risk assessment is a scientifically based and structural approached to ensure and evaluate the safety of food so that any possible microbiological hazard from food can be predicted and eliminated. MRA is used to establish standards, guidelines and other recommendations for food safety to enhance consumer protection and facilitate international trade (CAC, 1999). Industries use MRA as a useful tool in enabling the risk manager to consider and compare risk management options and to select control measures (Crossley \& Motarjemi, 2011).

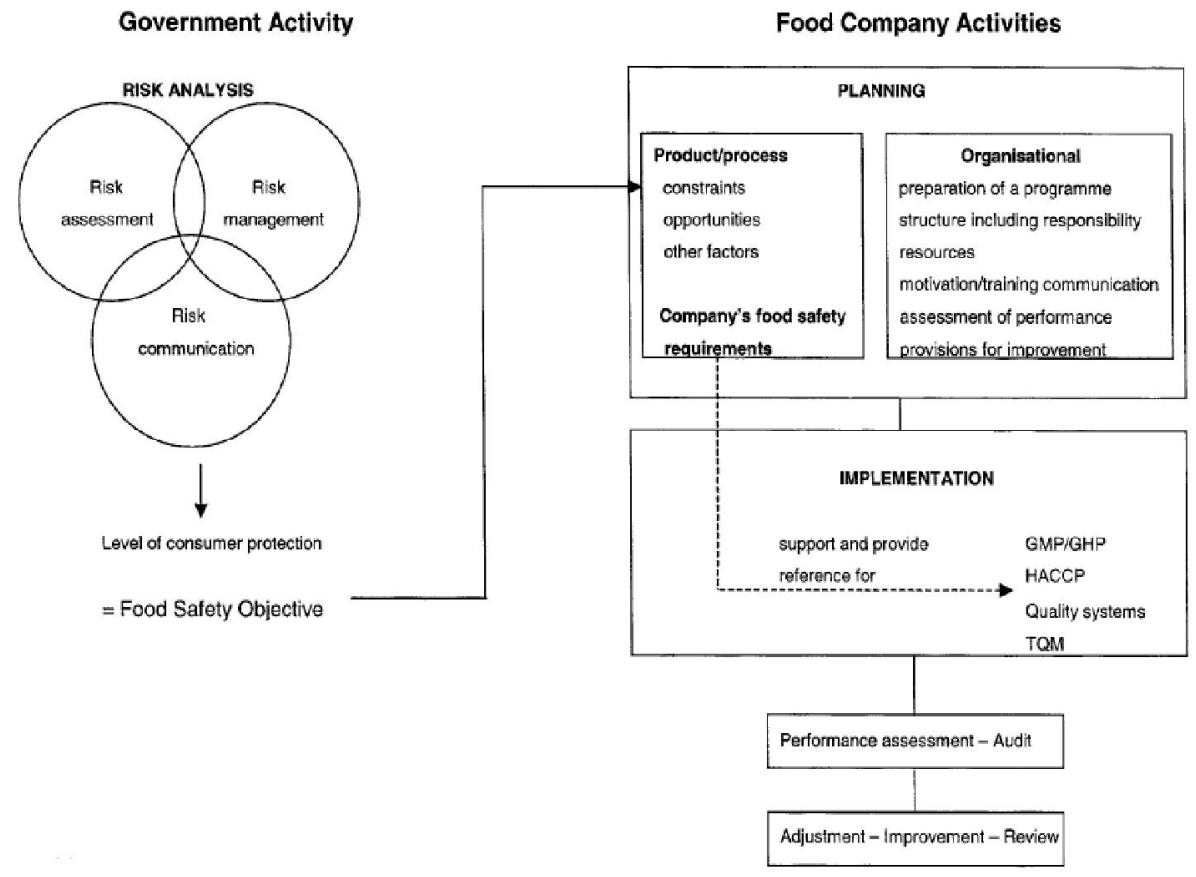

Figure 2. Interaction between government and companies in food safety activities (Forsythe, 2002). 
World Trade Organization (WTO) has set agreement on The Sanitary and Phytosanitary (SPS Agreement) in 1994 to be applied in international trade. This agreement includes consumer protection as well as prevention and reduction of risks which may arise from consuming food (Evans, 2009). By undersigning the SPS agreement, every food quality standard and regulation applied in every nation should be based on scientific approaches. Every nation should also perform risk assessment on imported products based on a principle prepared by Codex Alimentarius Commission (CAC) (Notermans et al., 2002). The principle consists of:

1. Hazard identification, to identify microorganisms in food which potential to cause an adverse health effect in human.

2. Exposure assessment, to qualitatively and quantitatively estimate the amount (dose) of microorganisms expose to human body due to consumption of food.

3. Hazard characterization, to qualitatively and quantitatively evaluate the source of adverse health effects related to microorganisms or their toxins.

4. Risk characterization, to qualitatively and quantitatively determine the estimation, such as uncertainty, probability of occurrence and severity level of potential adverse health effect in a given population.

SPS Agreement facilitates trade between countries in international level. Every country may choose their appropriate level of protection. Once a product does not confirm to the international standards or regulations, a risk assessment should be done by importing country to measure the risk and take corrective action. The measurement performs may differ between countries but it should be equivalent to achieve the international standards. However, scientifically based risk assessment is useful for further negotiation between importing and exporting country concerning minimum standards that has been set by the importing country.

\section{MICROBIOLOGICAL RISK ASSESSMENT OF FISHERY PRODUCTS}

Food Agriculture Organization (FAO) and World Health Organization (WHO) has been established a joint project to initiate the quantitative risk assessment of several pathogenic bacteria such as Salmonella in eggs and chicken, Listeria monocytogenes in ready

Table 1. Component of Microbiological Risk Assessment (Forsythe, 2002) 
combining the level of microbial contamination in food with the present foodborne outbreaks. Information obtained from the assessment was the probability of foodborne illnesses which may occur in a population when consuming contaminated food (Rocourt et al., 2003).

Related to fishery product, MRA that have been performed are MRA of $V$. vulnificus in fresh oyster, $V$. cholerae in shrimp, $V$. parahaemolyticus in mussels, and $L$. monocytogenes in ready to eat fish, salmon and grouper (Lindqvist \& Westoo, 2000; FAO/WHO, 2004; FAO/WHO, 2005a; FAO/WHO, 2005b, Yamamoto et al., 2008). MRA of fishery products in Indonesia is still limited. An effort to initiate such MRA in Indonesia is a hazard identification of pathogenic bacteria in shrimp (Dewanti-Hariyadi et al., 2002). The study showed that shrimp captured or cultured in several places in Java contained Salmonella at the concentration of 5.6-7.1 log cfu/g and E. coli at the concentration of $2.4-3.8 \log$ CFU $/ g$. These products also contain Vibrio cholerae, V. parahaemolyticus and L. monocytogenes.

Apart from fishery products, National Agency of Drug and Food Control (Badan Pengawas Obat dan Makanan) Republic of Indonesia has identified hazard of snack distributed in elementary schools. Up to 2005, the number of samples which were unfit for consumption has reached $39.95 \%$ and most cases were due to microbiological contamination (BPOM, 2006 in BAPPENAS, 2007).

\section{APROPOSED CONCEPTUAL MODEL FOR MICRO- BIOLOGICAL RISK ASSESSMENT OF VIBRIO PARAHAEMOLYTICUS IN SHRIMP PRODUCTS IN INDONESIA}

According to Ministry of Marine Affairs and Fisheries, total production volume of aquaculture fisheries has reached 6.9 million ton in 2011 with the highest 3.7 million ton from mariculture followed by 1.7 million ton from brackish water pond. The major commodities are seaweed, milkfish, tilapia and shrimp. Export value of shrimp itself to Japan, US, European Union and other countries has reached 152 thousand ton (USD 1.2 billion) in 2011 (MMAF, 2011b).

Related to the present of pathogenic microorganisms in shrimp, there are several studies which have been published. For captured and cultured shrimp in Java, the microorganisms found were Salmonella, E. coli, Vibrio cholerae, V. parahaemolyticus and L. monocytogenes (DewantiHariyadi et al., 2002; Yennie, 2011). In addition, recent data showed that $V$. parahaemolyticus has also been identified from shrimp originated from several fish processing units in East Java (Heruwati et al., 2011).

The expert consultation of FAO and WHO concluded that three species of Vibrio, i.e. Vibrio parahaemolyticus, V. vulnificus, and choleragenic $V$. cholerae, were the species responsible for most cases of human illnesses, and several seafood vehicles associated with these illnesses were identified (FAO/ WHO, 2005b).

Based on the available data and the importance to assess the risk of $V$. parahaemolyticus, this proposed study is aimed to study the risk of $V$. parahaemolyticus in shrimp products in Indonesia, particularly West Java and East Java. Risk assessment of $V$. parahaemolyticus in the harvesting point is based on the presence data of the microorganisms in pondsshrimp in West Java while the risk assessment of $V$. parahaemolyticus in the different step of production could be done in East Java where many fish processing units are exporting their shrimp products.

\section{The presence of $V$. parahaemolyticus}

V. parahaemolyticus is a gram negative, facultative anaerobic rod-shape bacteria which associated with gastrointestinal illness. In tropical and temperate regions, disease-causing species of Vibrio occur naturally in marine, coastal and estuarine (brackish) environments as well as from freshwater reaches of estuaries. The occurrence of these bacteria does not correlate with numbers of faecal coliforms and depuration of shellfish may not reduce their numbers. There is a positive correlation between water temperature and both the number of human pathogenic $V$. parahaemolyticus isolated and the number of reported infections (Sumner et al., 2004). V. parahaemolyticus occurs in a variety of fish and shellfish including clams, shrimp, lobster, crayfish, scallops and crabs as well as oysters. Oysters become the most common food associated with Vibrio infection in some countries (Hlady, 1997).

The infective dose is possibly greater than 1 million organisms and the virulence is due to the production of thermostable direct haemolysin ( $t d h)$, the ability to invade enterocytes and possibly the production of an enterotoxin (Forsythe, 2002). Studies in Japan showed that $96 \%$ of clinical strains produce $t d h$, subsequently $t d h$ negative strains were found to produce a $t d h$-related haemolysin. Both $t d h$ and trh are considered as pathogenic for human. Recently strains belonging to the 03:K6 serotypes have been found to be the causative agent of several outbreaks in different countries (WHO/FAO, 2011).

$V$. parahaemolyticus is very sensitive to heat, therefore the presence of this microorganism in cooked 


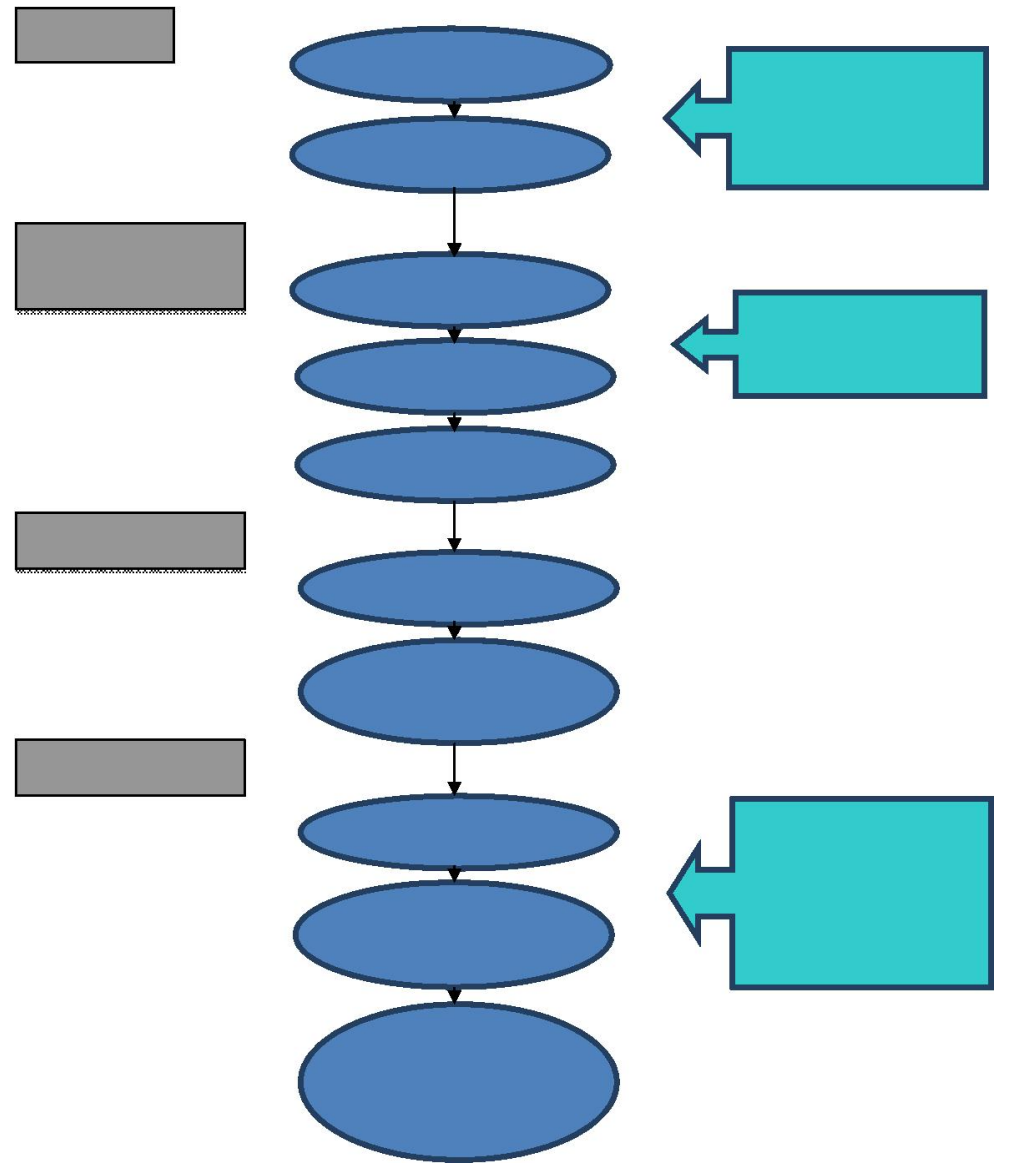

Figure 3. Proposed conceptual model of $V$. parahaemolyticus in shrimp.

Table 2. Influencing factors of the model 
Table 3. Required data to perform MRA of fishery product in Indonesia

Note: RDCMFPPB : Research and Development Center for Marine and Fisheries Product Processing and Biotechnology

AFQQCSFP : Agency of Fish Quarantine Quality Control and Safety of Fishery Product

food indicate a poor hygienic practice. Moreover, outbreaks are due to improper handling procedures and temperature abuse. Thus control of this microorganism should be done through the prevention of multiplication after harvesting by chilling (to below $5^{\circ} \mathrm{C}$ ) and cooking to an internal temperature of more than $65^{\circ} \mathrm{C}$ (Forsythe, 2002).
Several methods can be used for $V$. parahaemolyticus identification, including cultured based method (ISO, 2007) and molecular based methods such as PCR. However outbreaks report in Indonesia should also be collected from related institutions such as the Ministry of Health and the National Agency of Drug and Food Control. 


\section{The Proposed Risk Assessment Conceptual Model}

The proposed risk assessment conceptual model (Fig. 3) is based on the condition applied in Indonesia. The model is developed based on the conceptual model of $V$. vulnificus in oyster, $V$. cholerae in shrimp as well as $V$. parahaemolyticus in bloody clamps (FAO/WHO, 2005a, FAO/WHO, 2005b, Yamamoto et al., 2008). The model was based on the assumption that harvested shrimp is transported to the fish processing units for further processes. At the processing units, it is assumed that washing and antibacterial treatment will be taken place. The proportion of $t d h^{+}$and $t r h^{+}$in the total $V$. parahaemolyticus population is assumed to be constant.

The consumer data can be obtained through several methods. Firstly, through a direct interview on the amount of shrimp consumed per day and the actual cooking methods (time and temperature) of shrimp in a targeted population. Second is through a secondary data collection where some assumption will be made. The cooking methods can also be done through laboratory experiments where the time and temperature of the established cooking methods are modified.

A Beta Poisson model can be used to describe the dose response relationship. This model will estimate the probability (number) of illness ( $P$ ill) where the number of pathogenic $V$. parahaemolyticus ingested by a person in a meal (D) (Yamamoto et al., 2008). The dose response function combined with the output of exposure assessment will be used to estimate the yearly risk of $V$. parahaemolyticus.

$$
P(i l l)=1-\left(1+\frac{D}{\beta}\right)^{-\alpha} .
$$

Note: $\mathrm{P}$ (ill) $\quad$ : probability of illness

$$
\begin{array}{cl}
D \quad & \begin{array}{c}
\text { : the number of pathogenic } V . \\
\text { parahaemolyticus ingested }
\end{array} \\
\alpha \text { and } \beta & \begin{array}{l}
\text { : parameters for a beta-Poisson } \\
\text { dose-response model }
\end{array}
\end{array}
$$

Once the result of microbiological risk assessment showed that specific foods have potential hazard to consumers due to the present of pathogenic microorganisms or its toxins, the competent authority should decide appropriate control options to manage risks. As the result of risk assessment and risk management is to publish food safety objectives such as maximum level of a microbiological hazard in a food considering the consumer protection (Forsythe, 2002).
Finally, data needed to perform a microbiological risk assessment of $V$. parahaemolyticus in shrimp in Indonesia are summarized in the Table 3.

\section{CONCLUSION}

In food safety, consumer protection is the major of importance. As one of attempts to protect the consumer is through a risk assessment of food product. The proposed model on the microbiological risk assessment of $V$. parahaemolyticus of shrimp aimed to provide a scientifically structural approach to estimate the risk of $V$. parahaemolyticus due to shrimp consumption. However, the limitation of an integrated database should be solved with collaboration between institutions.

\section{REFERENCES}

Ababouch, L., Gandini, G., and Ryder, J. 2005. Causes of detentions and rejections in international fish trade. FAO Fisheries Technical Paper. 473.

Agency of Fish Quarantine, Quality Control and Safety of Fishery Products (BKIPM). 2012. Statistic of Fish Product Export $(\mathrm{Kg})$ Year 2011. Retrieved from http:// bkipm.kkp.go.id/statistik/. Accessed at May $28^{\text {th }} 2012$.

Canadian Food Inspection Agency (CFIA). 2012. Food Recall Report. Retrieved from http:// active.inspection.gc.ca/eng/corp/recarapp_dbe.asp. Accessed at January 2012.

Center of Disease Control (CDC). 2005. Foodborne illnesses. Retrieved from http://www.cdc.gov/ncidod/ dbmd/diseaseinfo/files/foodborne_illness_FAQ.pdf. Accessed at July 2011

Codex Alimentarius Commission. 1999. Principles and Guidelines for the Conduct of Microbiological Risk Assessment. CAC/GL-30. 1-6 p.

Crossley, S., and Motarjemi, Y. 2011. Food Safety Management Tools. $2^{\text {nd }}$ edition. ILSI Europe. Belgium. 12-20 p.

Desk, N. 2011. Listeria Test Prompts Seafood Recall. Food Safety News. Retrieved from http:// www.foodsafetynews.com/2011/11/listeria-testprompts-seafood-recall/. Accessed at May 2012.

Dewanti-Hariyadi R, Suliantari, Nuraida L, Fardiaz S. 2002. Determination of contamination profiles of human bacterial pathogens in shrimp obtained from Java, Indonesia. In Determination of Human Pathogen Profiles in Food by Quality Assured Microbial Assays. Proceedings of a Final Research Coordination Meeting held in Mexico City, Mexico, 2226 July 2002. Mexico: IAEA-Tecdoc-1431.

European Center for Disease Prevention and Control (ECDC). 2010. Food-borne disease. Retrieved from http://www.ecdc.europa.eu/en/healthtopics/ climate_change/ health_effects/Pages/food_borne_ diseases.aspx. Accessed at July 2011. 
European Food Safety Authorities (EFSA), Food-borne disease. Retrieved from http://www.efsa.europa.eu/ en/biohaztopics/topic/foodbornediseases.htm. Accessed at July 2011.

European Commission (EC). 2011. The Rapid Alert System for Food and Feed (RASFF) Annual Report 2010. European Communities. Luxemburg. p. 2831.

Evans, E.A. 2009. Understanding the WTO Sanitary and Phytosanitary Agreement. University of Florida. IFAS Extension. p. 1-5.

Food and Agriculture Organization (FAO)/World Health Organization (WHO). 2004. Risk assessment of Listeria monocytogenes in ready-to-eat foods. Interpretative Summary. Microbiological Risk Assessment Series 4.

Food and Agriculture Organization (FAO)/World Health Organization (WHO). 2005a. Risk assessment of Vibrio vulnificus in raw Oysters. Interpretative Summary and Technical Report. Microbiological Risk Assessment Series 8.

Food and Agriculture Organization (FAO)/World Health Organization (WHO). 2005b. Risk assessment of choleragenic Vibrio cholerae 01 and 0139 in warmwater shrimp in international trade. Interpretative Summary and Technical Report. Microbiological Risk Assessment Series 9. ISSN 1726-5274.

Food and Drug Administration (FDA). 1997. Food Code. US Department of Health and Human Services, Public Health Service, FDA, Washington DC, USA. In Huss, H.H., Ababouch, L. and Gram, L. 2004. Assessment and Management of Seafood Safety and Quality. FAO Fisheries Technical Paper 444. Rome.

Food and Drug Administration (FDA). US Food and Drug Administration. 2011. Import Refusal Report. Retrieved from $h t t p: / / w w w . a c c e s s d a t a . f d a . g o v / s c r i p t s /$ importrefusals/. Accessed at December 2011.

Food Standard Australia and New Zealand (FSANZ). 2012. Food Recall Statistic. Retrieved from http:// www.foodstandards.gov.au/consumerinformation/ foodrecalls/foodrecallstats.cfm. Accessed at January 2012.

Forsythe, S.J. 2002. The Microbial Risk Assessment of Food. Blackwell Science. p. 66-112.

Heruwati, E.S., Murtini, J.T., Ariyani, F., Dwiyitno, Andayani, F., Yennie, Y., Riyanto, R., Kusmarwati, A., Priyanto, N., Rachmawati, N., Triwibowo, R., and Putri, A.K. 2011. Quality assessment of fresh/processed fishery products and the determination of parameters and method used for products deterioration analysis and as quality standard tools as well as criteria determination. Technical Report. Research Center for Marine and Fisheries Product Processing and Biotechnology. Jakarta.

Hlady, W. G. 1997. Vibrio infections associated with raw oyster consumption in Florida, 1981-1994. Journal of Food Protection. 60:353-357.

International Organization for Standardization (ISO), 2007. Microbiology of food and animal feeding stuffs -
Horizontal method for the detection of potentially enteropathogenic Vibrio spp. - Part 1: Detection of Vibrio parahaemolyticus and Vibrio cholerae. Technical Specification 21872-1. Switzerland.

Japan External Trade Organization (JETRO). 2011. Guidebook for Export to Japan (Food Articles) 2011. Seafood and processed product. JETRO. Tokyo.

Lindqvist, R. and Westoo, A. 2000. Quantitative risk assessment for Listeria monocytogenes in smoked or graved salmon and rainbow trout in Sweden. International Journal of Food Microbiology. 58: 181196.

Ministry of Marine Affairs and Fisheries. 2011a. 2012, Fishery export target should reach US $\$ 3,60$ billion. Retrieved from http://www.kkp.go.id/index.php/arsip/ c/6189/2012-Target-Ekspor-Perikanan-US360Miliar/?category_id=. Center of Data and Information MMAF. Accessed at January 2012.

Ministry of Marine Affairs and Fisheries. 2011b. Marine and Fisheries in Figures 2011. Center of Data Statistic and Information. p. $30-35$.

Miraglia, M., Marvin, H.J.P., Kleter, G.A., Battilani, P., Brera, C., Coni, E., Cubadda, F., Croci, L., de Santis, B., Dekkers, S., Filippi, L., Hutjes, R.W.A., Noordam, M.Y., Pisante, M., Piva, G., Prandini, A., Toti, L., van den Born, G.J., and Vespermann, A. 2009. Climate change and food safety: An emerging issue with special focus on Europe. Food and Chemical Toxicology. 47:10091021.

Notermans, S., Barendsz, A.W., and Rombouts, F. 2002. The Evolution of Microbiological Risk Assessment in Food Production. In Brown, M. and Stringer, M. (Eds). Microbiological risk assessment in food processing. Woodhead Publishing Limited. Cambridge.

Rocourt, J., BenEmbarek, P., Toyofuku, H., and Schlundt, J. 2003. Quantitative risk assessment of Listeria monocytogenes in ready-to-eat foods: the FAO/WHO approach. FEMS Immunology \& Medical Microbiology. 35 (3): 263-267.

Schothorst, M. 2002. Microbiological risk assessment of foods in international trade. Safety Science. 40 : $359-382$.

Sumner, J., Ross, T., and Ababouch, L. 2004. Application of risk assessment in the fish industry. FAO Fisheries Technical Paper 442.

The National Development Planning Board (BAPPENAS). 2007. Food and Nutrition National Action Planning 2006 - 2010. ISBN 978-979-3764-27-6.

United States Food and Drug Administration (USFDA). 2012. Recall, Firm Press Release. Retrieved from http://www.fda.gov/Safety/ Recalls/ucm286708.htm. Accessed at 17 January 2012.

World Health Organization (WHO) and Food and Agriculture Organization (FAO). 2008. Exposure assessment of microbiological hazard in food. Guidelines. Microbiological Risk Assessment Series 7.

Yamamoto, A., Iwahori, J., Vuddhakul, V., Charernjiratragul, W., Vode, D., Osaka, K., 
Shigematsu, M., Toyofuku, H., Yamamoto, S., Nishibuchi, M., and Kasuga, F. 2008. Quantitative modeling for risk assessment of Vibrio parahaemolyticus in bloody clams in southern Thailand. International Journal of Food Microbiology. 124: $70-78$.
Yennie, Y. 2011. Isolation and identification of pathogenic Vibrio parahaemolyticus in pond shrimp. Thesis. Faculty of Agriculture Technology. Post Graduate School. IPB. 